шения является адаптация к системе управления электромеханической системой.

Практическая значимость. Параллельный робот, состоящий из трех рычагов, присоединенных с помощью карданных шарниров к основанию, является наиболее эффективным, когда необходимо быстро осуществлять перемещение по сложной или простой траектории, одновременно изменяя координаты $x$, $y$ и $z$. Этот факт делает актуальной задачу разработки алгоритма получения математических выражений для одновременного управления электродвигателями дельта-робота. Полученные математические выражения для прямой и обратной задач кинемати-

UDC 681.5.015: 622.693.4

I. M. Udovyk, Cand. Sc. (Tech.), Assoc. Prof., orcid.org/0000-0002-5190-841X,

A. I. Simonenko, Cand. Sc. (Tech.), Assoc. Prof., orcid.org/0000-0002-5584-3617,

O.A. Zhukova,

orcid.org/0000-0002-1619-9582,

S. D. Prykhodchenko,

orcid.org/0000-0002-6562-0601 ческого анализа являются первым шагом в разработке системы управления, обеспечивающей координацию и согласованность требуемых перемещений всех исполнительных органов в соответствии с указанной программой, которая понимается как набор инструкций для обеспечения реализации технологического процесса.

Ключевые слова: дельта-робот, обратная кинематика, прямая кинематика, электромеханическая система

Рекомендовано до публікації докт. техн. наук C.I. Випанасенком. Дата надходження рукопису 22.12.16.

DOI: $10.29202 /$ nvngu/2018-1/12

National Mining University, Dnipro, Ukraine, e-mail: udovyk. i.m@nmu.one; symonenko.o.i@nmu.one; zhukova.o.a@nmu. one; prykhodchenko.s.d@nmu.one

\title{
ELECTROMECHANICS SYSTEM MODELLING OF HYDROTRANSPORT AT AN ENRICHMENT PLANT
}

І. М. Удовик, канд. техн. наук, доц., orcid.org/0000-0002-5190-841X, О. І. Симоненко, канд. техн. наук, доц., orcid.org/0000-0002-5584-3617, О.А. Жукова, orcid.org/0000-0002-1619-9582, С. Д. Приходченко, orcid.org/0000-0002-6562-0601
Державний вищий навчальний заклад „Національний гірничій університет“, м. Дніпро, Україна, e-mail: udovyk. i.m@ nmu.one; symonenko.o.i@nmu.one; zhukova.o.a@nmu.one; prykhodchenko.s.d@nmu.one

\section{МОДЕЛЮВАННЯ ЕЛЕКТРОМЕХАНІЧНОЇ СИСТЕМИ ГІДРОТРАНСПОРТУ ЗБАГАЧУВАЛЬНОЇ ФАБРИКИ}

Purpose. To construct and analyze electromechanical system model for hydrotransport used at factories, that will be able to take into account changes related to equipment wear, and also produce the accumulation of technical changes caused by the exploitation of the pipeline system.

Methodology. The dynamic model of the electromechanical system of hydrotransport is developed on the basis of data about physical parameters of hydrotransport systems, received empirically. It is based on the methods for identification of dynamic systems in the form of differential equations for elements of the inside-factory hydraulic transport technological object.

Findings. A model of the electromechanical system of hydrotransport is developed. Verifications of homogeneity by the Fisher's and Bartlett's criteria showed the homogeneity of the estimates of the variance of reproducibility. For the Fisher's criterion rating was 2.59; for the Bartlett's criterion verification showed that the coefficient is significant at the level less than 0.02 , and this is indicating the reliability of the calculation of the correlation matrix.

Originality. For the first time a model for systems of the hydraulic transport, based on the Jeffcott's multi-mass rotor models, was applied. While modelling, wear of equipment in process is taken into account.

Practical value. Efficiency of usage of Jeffcott's multi-mass rotor models based model, has been proven. It allows describing the behavior of an object in specific technological regimes reliably and improves efficiency of the processes.

Keywords: dynamic modeling, Jeffcott's rotor, multi-mass model, hydrotransport

(C) Udovyk I. M., Simonenko A. I., Zhukova O.A., Prykhodchenko S. D., 2018 
Introduction. The share of mining and metallurgical production in Ukraine in 2010 accounted for $22.8 \%$ of all electricity consumed in the country. At the same time from 40 to $70 \%$ of the cost of mineral processing is spent on the transport systems used at enterprises of mining industry. That is why the problem of reducing energy consumption on the hydrotransportation of materials inside enterprises is one of the most important tasks of modern mining and processing complex and Ukraine in general.

Monitoring of performance characteristics of slurry pumps, which are widely used for ore beneficiation, can give from 9 to $21 \%$ of power consumption save, where the upper limit depends on structural improvements, and the lower one depends on timely and full servicing of pumps. Foregoing information shows, that the urgent task is to develop integrated methods for control and diagnostics of the hydraulic system.

Analysis of the recent research and publications. From the work [1] we can conclude that the results of hydrotransportation systems vibro-diagnostics are able to detect most emergency and pre-emergency conditions of hydrotransport, used at factories. However, vibro-diagnostic systems are often not included in Automatic Technique Processes Control Systems neither as inside-factory hydraulic transport nor as enterprise ACS because of their low reliability, and need for further development of the main technological equipment, for installation of transducers, bad operating conditions, latest [2]. But nearly all modern control systems contain sensors that control basic electrical stats, such as: current consumption, the voltage, and power consumption [1, 2]. Therefore, it was decided that it would be better to construct the mining and processing enterprise hydrotransportation diagnostic system, based on data from sensors which are already installed in the process control system of mining and processing enterprises.

Moreover, preliminary research studies [1] showed that the availability of information about the mechanical parameters of hydrotransport system and spectrogram of instantaneous active power, which is consumed, give an idea of the current vibrating activity of inside-factory hydraulic system. This allows using research in the field of vibro-diagnostic results, for the diagnosis of inside-factory hydrotransport system (IFHTS) according to the stats of the instantaneous active power consumption spectrum of slurry pump drive motor.

The analysis showed that most of the models are either based on empirical data and are poorly applicable for constructing ACS of hydrotransport system with different material components and the geometry of pipes, or do not take into account the processes of wear and pre-crash situation the control of which is particularly important for the current diagnosis [3-5].

Objectives of the article. Thus, the goal of this research is to build models of Electromechanical systems for inside-factory hydrotransport applicable for the analysis of technological processes of hydrotransportation, that can take into account changes as a result of equipment wear and the accumulation of technical changes, caused by the operation of the pipeline system.
Methods. For models of electromechanical insidefactory hydrotransport system building identification methods of dynamic systems in the form of differential equations for elements of the inside-factory hydraulic transport as a technological object will be used.

Presentation of the main research and explanation of scientific results. Operational diagnostics of hydrotransport systems allows determining the type of the defect occurring and the amount of repair work needed for its elimination before the onset of the emergency and preemergency status of the system. It is desirable to include estimates of the pre-repair and post-repair conditions in process of diagnosis of hydrotransport system.

It is advisable to monitor the oscillations, produced by the system, for condition control of hydrotransport system. As shown in [1], such variations have a proportional influence on the consumption of system energy, which allows you to replace the process of vibro-diagnostics of hydrotransport system with the process of energy diagnostics. The identification of such fluctuations should be done comprehensively and not only for discrete components, but for the entire spectrum of vibrations in general, due to the ambiguity of stochastic relations between the technological parameters.

The basic premise of electromechanical unit energy diagnostics technologies is the scope of development and practical implementation of methods for isolation and estimation of informative parameters of the technical condition of the diagnosed object on the characteristics of energy consumption of the facility.

Vibrations are caused by disturbing forces which arise when machines work. The sources of vibrations can be either elements reciprocating motions, or unbalanced masses, such as rotors of electrical machines, shafts and bearings, rotations as well as rotation of any elements of the mechanism, in which imbalance, wear and tear can appear due to inaccuracies of manufacture or constructive features of the machine. Frequency of the forced hydrotransport system oscillations is determined by the frequency of disturbing force. If disturbing force occurs due to rotation of an unbalanced mass with angle velocity $\omega$, then frequency of forced oscillations is equal to $\omega$, while the vibrational displacement of the unit is changed by the harmonic law $y=u(t) \cdot \sin (f t)$ where $y$ is displacement of unit, $m ; u(t)$ is the amplitude of displacement, $m ; t$ is time, sec; $f$ is forced oscillation frequency, $\mathrm{Hz}$. The physical basis of energy diagnostics method is the law of energy conservation. Conducted simulation modeling excluding the nonlinear characteristics of interaction showed $98.2 \%$ correlation between the results of vibro-diagnostics and energy diagnostics, which suggests the possibility of using energy diagnostics, based on previous research results in the field of vibration diagnostics.

Based on the work of $[1,2,5]$, we will take jet slurry pump, the dynamic model proposed in [1], which was given the parameters of the engine 5AM315S4, that has been used at 2 EP Poltava GOK, as a primary hydrotransportation system host.

Structural diagram of a simulation model, implemented according to [6] gives the opportunity to consider processes with the greatest approximation to the real AD, 
which is useful in research of static and dynamic modes, Fig. 1.

Typical single hydrotransport system consists of receivers and pressure tanks with necessary valves, pipelines, slurry pump (EE), an electric motor, the system of measuring instruments and devices required to fill slurry pump with liquid before start-up. In addition, hydrotransport system elements list includes such components as: starting device of motor, slurry pump and assemblies of automatic control SP and inside-factory hydrotransport system (IFHTS) in general. The structure of isolated single inside-factory hydrotransport system is shown in Fig. 2. In terms of mining and processing, the inside-factory hydrotransportation system consists of sequential and parallel single systems.

Based on the results of Jeffcott-Laval's [2, 7] multimass rotor systems research studies as well as above said, it is possible to present Fig. 3 as a mechanical component. Then the total electro-mechanical circuit can be represented as Fig. 4.

As shown in [2,3], the condition of slurry pump impeller may be represented in Jeffcott-Laval's form of rotor. This model involves the elastic deflection of unit rotating element from the axis of rotation, which allows making simulation of wear in process. Extrapolating this research to all rotating elements IFHTS, in the form of a rotating mass with changing in process of wear, eccentricity,

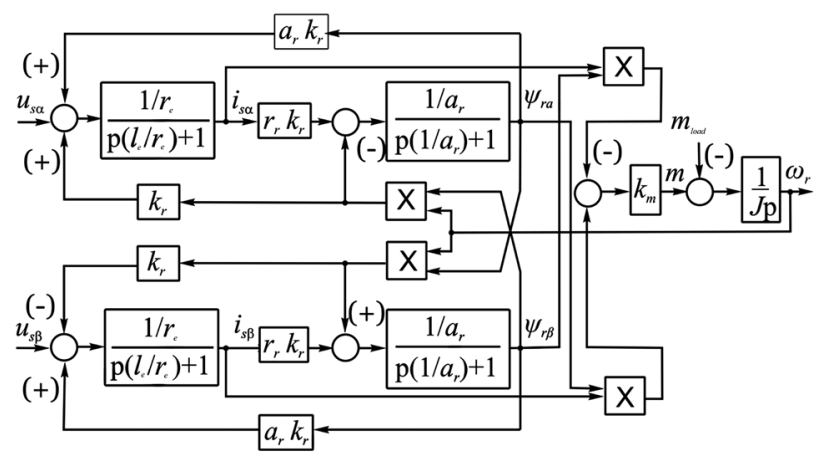

Fig. 1. Structural diagram of a simulation model of $A D$ in stationary coordinate system

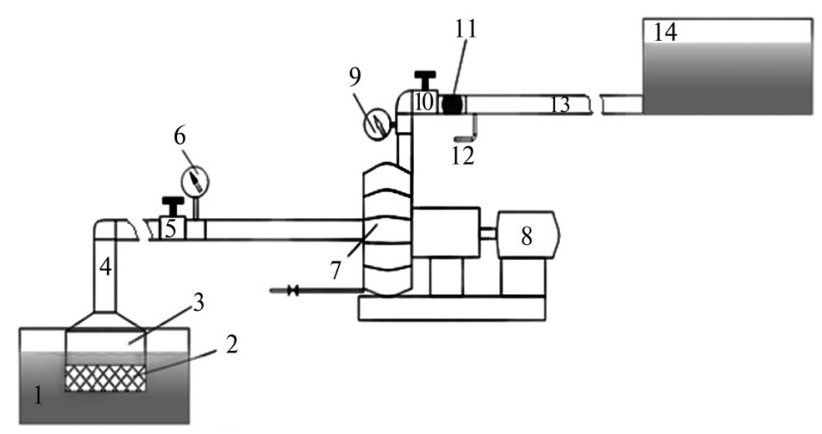

Fig. 2. Structure of elementary hydrotransport system: 1 - receiving tank; 2 - intake grid, 3 - receiving valve; $4-$ suction pipe; 5 - mounting damper; 6 - vacuum gauge; 7- pump. 8 - electric motor; 9 - pressure gauge; $10-$ control flap; 11 - check valve; 12 - flow meter; 13 - pressure pipe; 14 - receiving tank can give an ability to model all the rotating elements of hydraulic system mining and processing enterprise, i.e., it is acceptable to assume a slurry pump as Jeffcott-Laval's multi-mass rotors system.

To confirm this thesis, simulations, which were made in Matlab, were designed in stages to test the parts of the IFHTS model. So, at the first stage, IFHTS management is to limit the critical speed of rotation. Then undamped critical speed and the relative damping will be expressed as follows [4]

$$
\begin{aligned}
& \omega_{k}=\sqrt{\frac{k}{m}} ; \\
& \xi=\frac{c}{2 \cdot \sqrt{k \cdot m}} ; \\
& \varepsilon=\frac{m_{u} \cdot r_{u}}{m}
\end{aligned}
$$

where $m$ is the rotor mass; $c$ is the coefficient of damping; $k$ is the stiffness coefficient; $m_{u}$ is the unbalanced mass; $r_{u}$ is the distance from the disk center to the center of mass; $\omega$ is the speed rotation; $i=\sqrt[2]{-1} ; t$ is the time variable.

The first stage of constructing a model based on a Jeffcott-Laval's rotor system, was the construction and modeling of single-mass model, that simulates the rotor of the drive motor 5AM315S4 with deflection (Fig. 5), which is the first element of the system.

Relying on technological parameters of the mechanism, for slurry pump model 5-Grk8 we assume that the rotor mass $=450 \mathrm{~kg}$, unbalanced mass $=100 \mathrm{~kg}, r_{u}=0.01$, $\varepsilon=100 * 0.01 / 450=0.002222$ and $c=562, m=450, k=$ 281250, $\omega_{k}=\sqrt{\frac{k}{450}}=25$, reaction of the rotor is defined as equation (1).

$$
\mid G(s)=\frac{\varepsilon \cdot \omega^{2}}{s^{2}+2 \cdot s \cdot \xi \cdot \omega_{n}+\omega_{n}^{2}} .
$$

The analysis of rotor model transition function graph revealed that the system response has the character of damped oscillations, with the transition to the constant vibration activity, as expected when damping coefficient $=0.03$.

For submission of the slurry pump in Jeffcott-Laval's rotors form it is believed that every moving element of the mechanism is represented in the form of JeffcottLaval's rotor, connected to the adjacent elements of the elastic connection (Fig. 6). Then slurry pump model block diagram expressed in the form of multi-mass rotors system, excluding drive motor shaft, can be represented as the circuit shown in Fig. 7.

The mathematical description of the pressure-flow characteristics of the pump is written in the following form [8]

$$
H=h_{0} \cdot \omega^{2}+b \cdot \omega-r_{n} \cdot q^{2},
$$

where $h_{0}$ is the corrected pressure of the idling pump; $b$ is the coefficient characterizing the linear relationship between pressure and pump flow; $r_{n}$ is the coefficient char- 


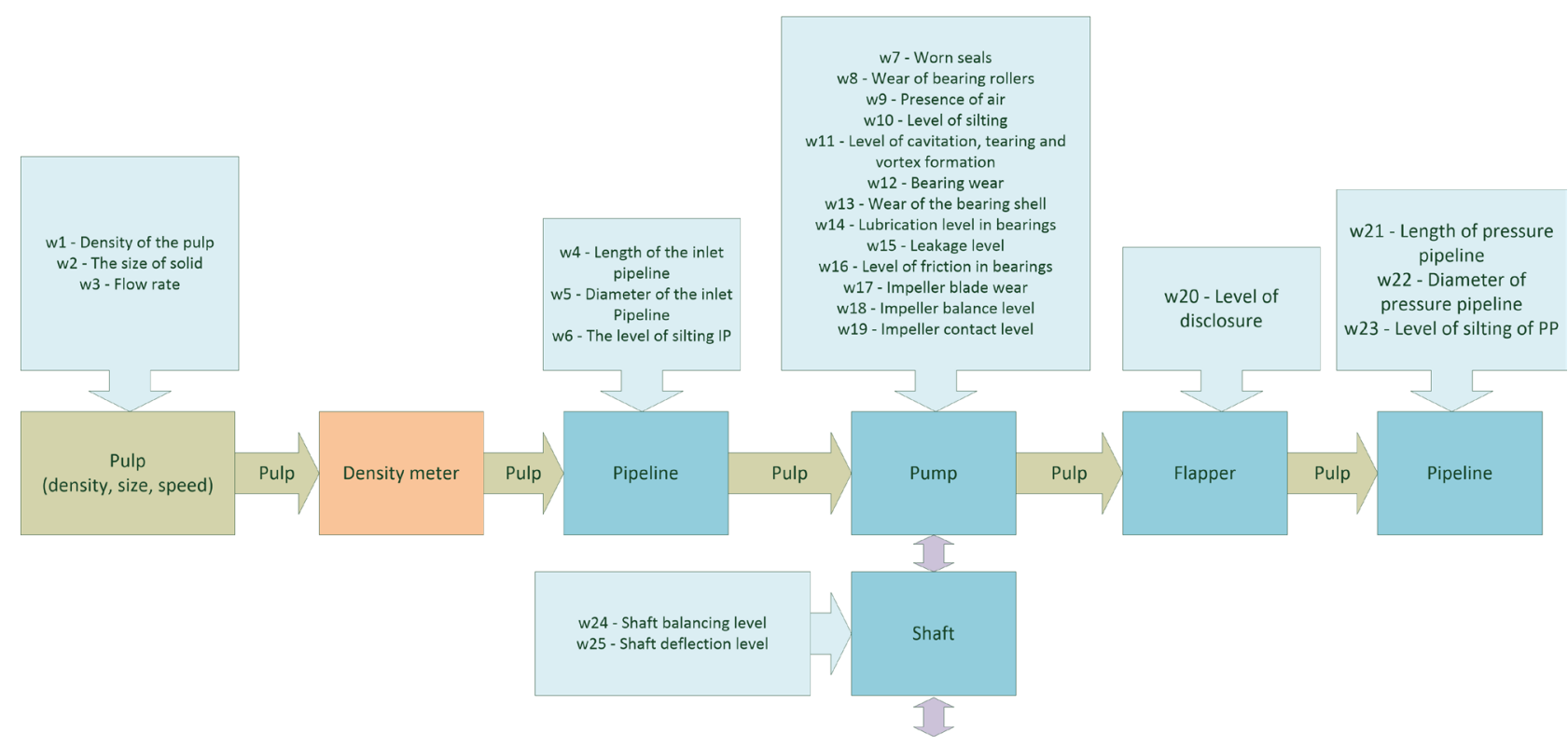

Fig. 3. Diagram of the mechanical components of the IFHTS model

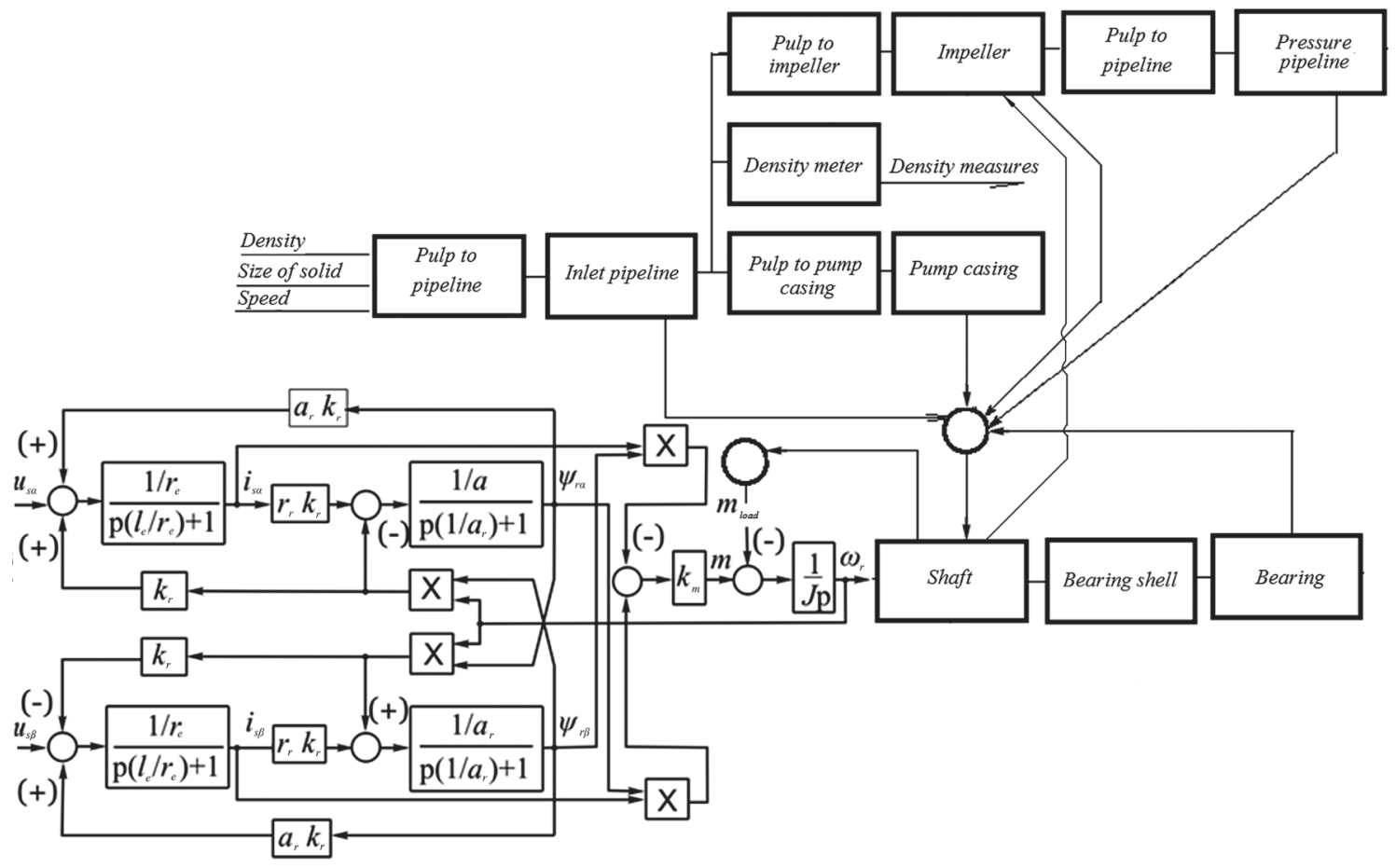

Fig. 4. Electro-mechanical diagram of Inside-factory hydrotransport system model

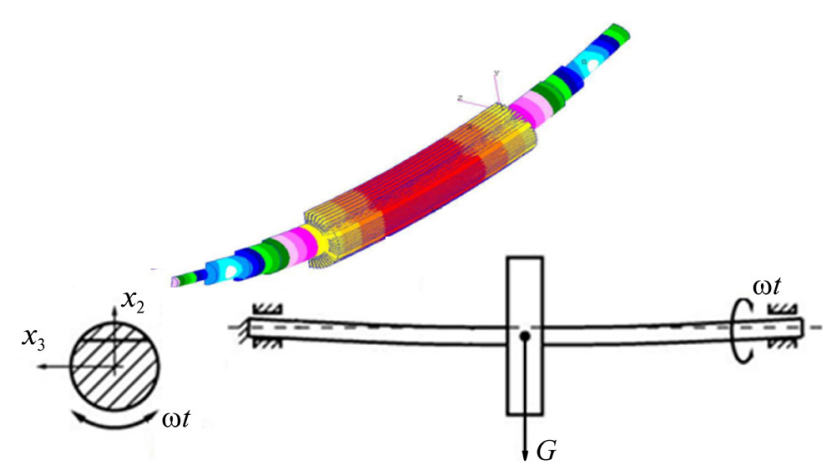

Fig. 5. Simulation of bending of a rotor of the drive motor

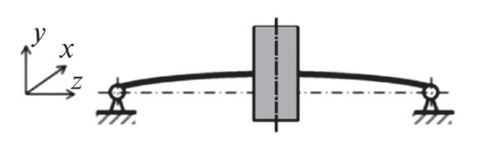

$a$

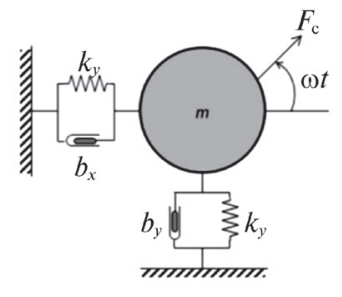

$b$

Fig. 6. Jeffcott's model of the rotor, connected to adjacent elements by the elastic connection:

$a$ - Jeffcott rotor physical model; $b$ - Jeffcott rotor simplified model with dampers and springs (Muszyńska A.) 


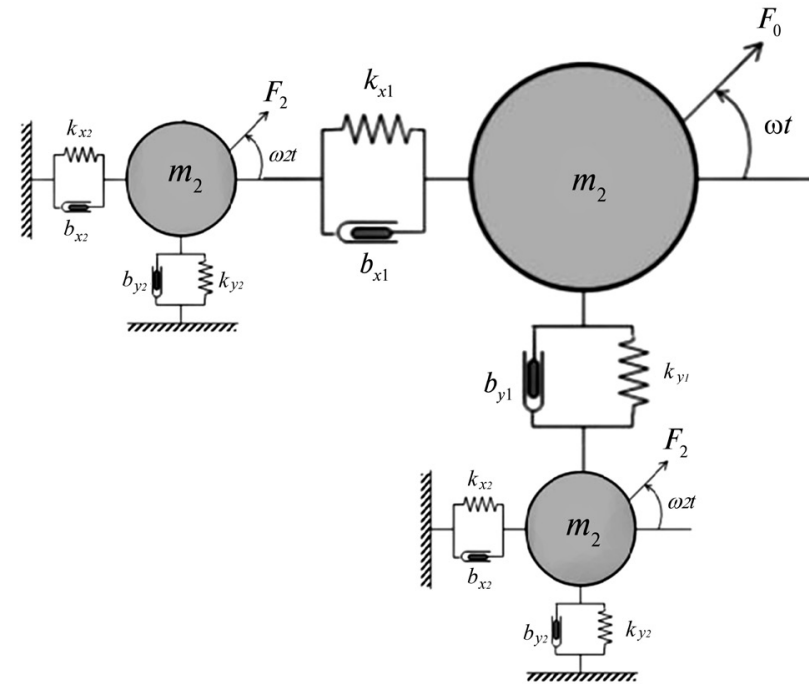

Fig. 7. Structural scheme of slurry pump model, expressed in the form of multi-mass system rotors

acterizing the internal hydraulic resistance of the pump; $\omega-$ is the frequency of rotation; $q$ is the pump flow.

The first two members in equation (2) determine the process of energy transfer from the impeller of the liquid, and the third member determines the centrifugal pump total losses, which are proportional to the square of performance. We denote the dynamic component of the characteristic of centrifugal pump to obtain the dependencies characterizing the behavior of the pump in the dynamics

$$
z=h_{0} \cdot \omega^{2}+b_{0} \cdot \omega .
$$

The dynamic characteristics of the pump that takes into account transitional processes in it can be represented in the form [4]

$$
T_{H} \cdot \frac{d z}{d t}+z=b \cdot \omega+h_{0} \cdot \omega^{2}
$$

or

$$
z=\frac{1}{T_{H} p+1}\left(b \cdot \omega+h_{0} \cdot \omega^{2}\right)
$$

It should be noted that the pump system FT - AE (Fig. 8) with feedback speed represents a unified mechanism, which has a multi-mass swing system that is composed of a rotor motor, the bearing system and impeller of the pump. The element, that reflects dynamic characteristic of the pump that takes into account transients, is added to this impeller.

It is necessary for separate pipeline sections not to enter the phase of active mechanical resonance caused by compressors, pumps or the unsteadiness of flow in order to guarantee that piping system is free from excessive vibrations. To achieve this goal, frequency of the excitation forces and mechanical natural frequencies of the pipeline need to be calculated.

The actual oscillation frequency of pipeline sections often deviates from the theoretical frequency, as configurations that exist in the real factory pipelines have boundary conditions that differ from the ideal values. However, theoretical research studies [3, 7] provide a valuable starting point for understanding the behavior of pipeline vibration. To obtain a model of hydrotransport system, elements are added sequentially to the pump model (Fig. 7) to simulate the interaction of the pump with pulp and the pipeline. Current hydrotransport system consists of tree pipes connected at $90^{\circ}$ angle; length of each pipe equals 3 meters. That construction takes the actual situation of the pipeline, the way it is shown in [1], can influence the vibrations of the pulp, i.e., to produce change of the power expended in pumping the pulp required when considering a full model of the system hydrotransportation. To determine the parameters of this level we will refer to [5, $8-10]$, where $\mathrm{F}_{u}=75.8 \lambda\left(\mathrm{D} / \mathrm{L}^{2}\right), \lambda=23.4, \mathrm{D}=0.1, \mathrm{~L}=3$, which gives the value of the frequency of vibration of 19.97 , i.e. fully confirming the assumption of vibratory activity

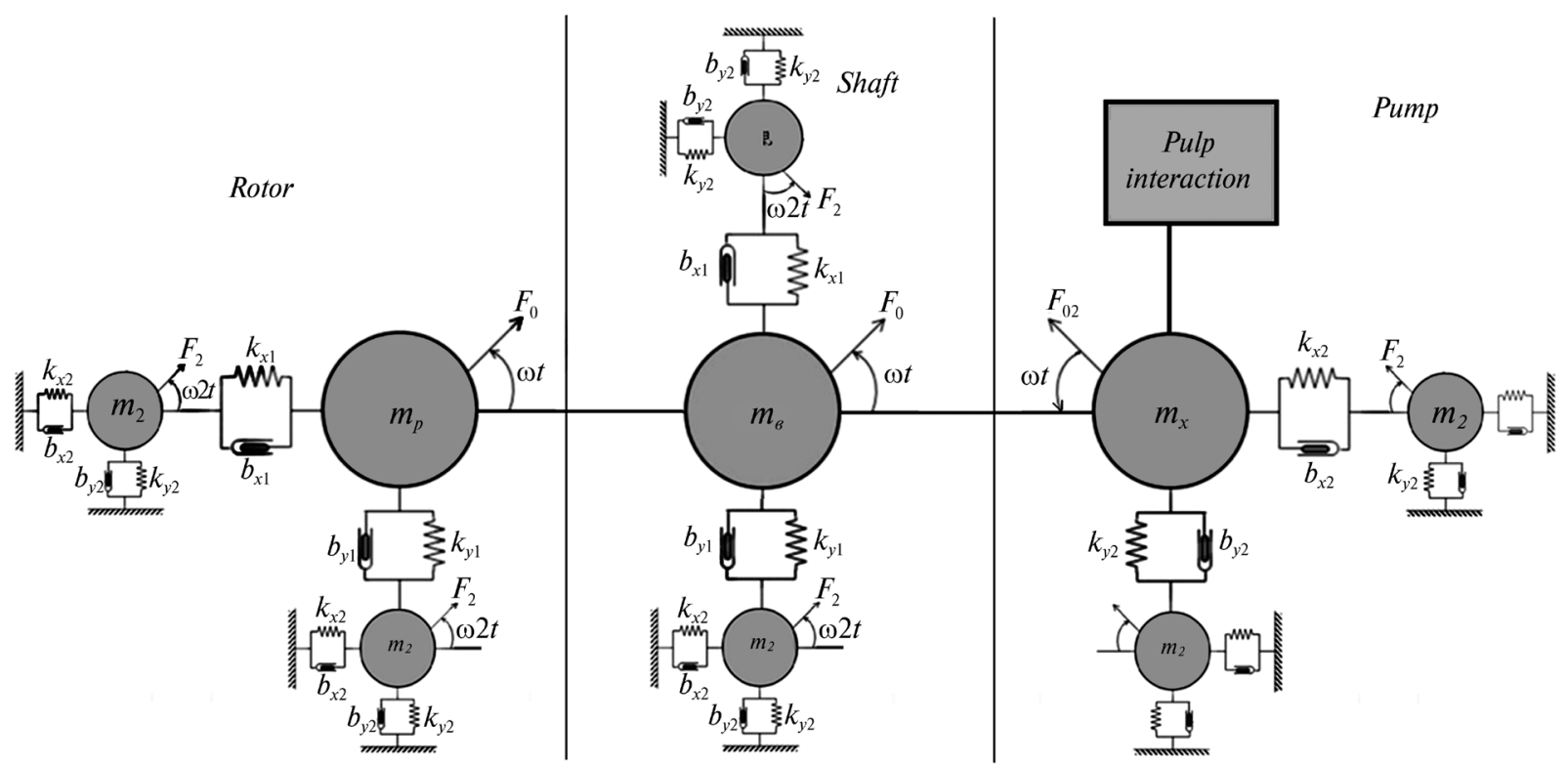

Fig. 8. Structural scheme of the model slurry pump, coupled with AD expressed in the form of multi-mass rotors system 
caused by the bending of the pipeline. Then the formula of the transfer function of the additional link will be expressed as a formula for vibrational level of the second order

$$
W(p)=\frac{1}{T^{2} p^{2}+2 \xi T p+1^{2}},
$$

where $p_{1,2}=\frac{\xi}{T} \pm j \frac{1}{T} \sqrt{1-\xi^{2}}=\alpha \pm j \omega ; \alpha$ is the attenuation coefficient; $\omega$ is the angular frequency.

The unit attached to the system and simulating the interaction of the pump with the pulp, allows obtaining the following data on a frequency response for slurry pump, filled with pulp (Fig. 4). Entering the unit into the resulting system-level model the interaction of pump and pipeline, which transported the pulp, we get the following data for frequency response for IFHTS (Fig. 9). The study frequency response is made at linear models of the automatic control system (ACS) developed in the "MATLAB Simulink".

To check the adequacy of the model of the Electromechanical system of hydrotransport, the following actions were performed:

1. The experiment was carried out at Poltava GOK [11].

2. A range of harmonic energy-information of the indications of the model of the Electromechanical system, hydraulic concentrator, was calculated.

3. The experimentally obtained values and values obtained using the model, were subjected to correlation and spectral analysis.

4. Homogeneity was checked according to the criteria of Fisher and Bartlett, which showed the homogeneity of the estimates of the variance of reproducibility, for the Fisher test rating was 2.59; for the Bartlett criterion test showed that the coefficient is significant at the level less than 0.02 , indicating that the reliability of the calculation of the correlation matrix.

5. On the basis of previously collected data, the adequacy of the proposed models was tested by comparing the variance of reproducibility of the average value of the response function $s$ and variance of adequacy.

In the actions described above the following results were obtained: assessment of the adequacy of the model and the experimental data showed that the estimate of the variance adequacy of the model is significantly less than the table values, which confirms the high accuracy of con-

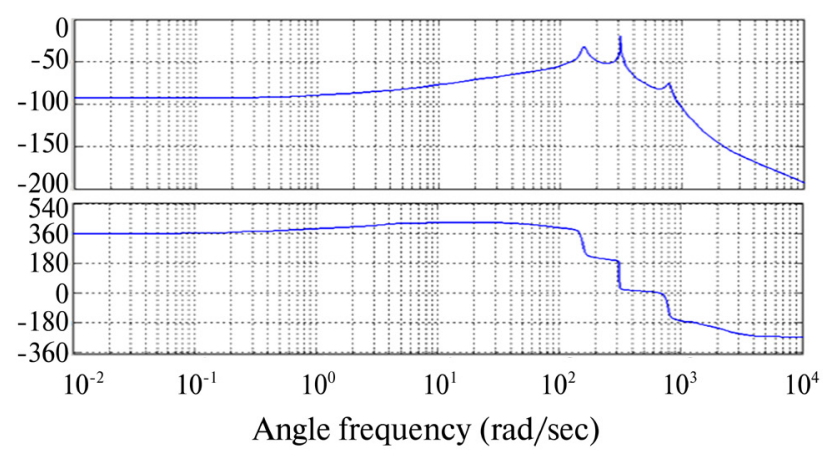

Fig. 9. Frequency response for IFHTS phase flotation 2 EP PGOK vergence of theoretical and experimental data and adequacy of the proposed model.

Conclusions. Thus, the proposed IFHTS model using the method of linear elements based on the use of multimass rotor models of Jeffcott-Laval, allows you to simulate the wear of the equipment, which in this model is provided by changing the coefficients of the transfer functions of individual units. In studies of the dynamics of the pipeline transport it is important to reliably describe the behavior of the object in specific technological regimes. It is worth noting that the hydrotransport system is a complex stochastic object because of on-going technological processes of various nature, in particular hydrodynamic, heat and mass transfer. Mathematical modeling of the dynamics of pipeline systems must include: calculations of operational modes, including transient ones, in the normal mode of operation; analyses of potential emergency and pre-emergency situations associated with a deviation from normal operating conditions. To assess the behavior of the system in these modes, it is necessary to pre-model all possible states, which will significantly accelerate the determination of the current status of the system, which in turn will allow a more qualitative analysis of the situation.

\section{Reference.}

1. Prykhodchenko, S. D., 2014. Modelling of slurry hydrotransport system to slurry storage. Metallurgical and mining industry: scientific, technical and industrial journal, 2(287), pp. 97-100.

2. Afanasiev, Yu. V., Polikhach, E. A., Yamalov, I. I. and Farrakhov, D. R., 2012. Application of an asynchronous drive for simulating the mechanical characteristics of general industrial mechanisms. Vestnyk UGATU [online], 16(8(53)), pp. 136-140. Available at: <https://cyberleninka.ru/article/n/primenenie-asinhronnogo-privodadlya-imitatsii-mehanicheskih-harakteristik-obschepromyshlennyh-mehanizmov> [Accessed 28 August 2017]. 3. Thiery, F., 2016. Simplified Models to Evaluate Nonlinear Dynamics in Hydropower Rotors. Lulea University of Technology.

4. Khrbchek, Y., Shymak, V. and Yanota, A., 2014. Prognostic control of rotor radial models. Technological machines, 1(44), pp. 83-89.

5. Chao-Zhong Guo, Ji-Hong Yan and Lawrence A. Bergman, 2017. Experimental Dynamic Analysis of a Breathing Cracked Rotor. Chinese Journal of Mechanical Engineering [online]. Available at: <http://paperity.org/p/80389310/ experimental-dynamic-analysis-of-a-breathingcracked-rotor $>$ [Accessed 15 September 2017].

6. Murashkin, S. I., 2012. Non-synchronous variable-frequency electric drive with vector control. The Bulletin of KrasGAU [online], 9, pp. 189-196. Available at: <https:// cyberleninka.ru/article/n/asinhronnyy-chastotnyy-elektroprivod-s-vektornym-upravleniem $>$ [Accessed 5 June 2017].

7. Lipika Sharma and Shailja Shukla, 2013. Application of Model Predictive Control for Improving Stability of Rotor and Controlling Active Rotor Vibration. International Journal of Computer Applications (0975-8887), 72(13), pp. 17-22.

8. Semenenko, E. V., Kirichko, S. N. and Nikiforova, N.A., 2015. Methodology for calculating the operating modes 
of modernized systems of pressure pipeline transport. In: Proceedings of the International Conference "Forum for Climate Change 2015", Dnipropetrovsk, NSU [online], 1, pp. 235-241. Available at: <http://ir.nmu.org.ua/bitstream/handle/123456789/150535/235-241.pdf? sequence $=1 \&$ isAllowed $=\mathrm{y}>$ [Accessed 21 April 2017].

9. Zachwieja, Ja., 2017. Stress analysis of vibrating pipelines. AIP Conference Proceedings 1822, 020017 (2017); DOI: $10.1063 / 1.4977691$.

10. Ristaniemi, A., 2015. Linearization of piping supports in dynamic analyses [pdf]. Available at: <https:// aaltodoc.aalto.fi/bitstream/handle/123456789/18139/ master_Ristaniemi_Aapo_2015.pdf> [Accessed 5 July 2017]. 11. Prykhodchenko, S. D., 2007. Analysis of the results of industrial tests of slurry pump motors [online]. Available at: <http://www.vuzlib.com.ua/articles/book/1366Analiz_rezultatov_promyshlenny/1.html $>$ [Accessed 11 August 2017].

Мета. Побудова та аналіз моделі електромеханічної системи гідротранспорту збагачувальних фабрик, що зможе враховувати зміни, пов'язані зі зношеністю обладнання, а також накопичувати технічні зміни, викликані експлуатацією трубопровідної системи.

Методика. Динамічна модель електромеханічної системи гідротранспорту розроблена на основі даних про фізичні параметри гідротранспортних систем, отриманих емпірично. Вона базується на методах ідентифікації динамічних систем у вигляді диференціальних рівнянь для елементів технологічного об'єкта гідравлічного транспорту всередині заводу.

Результати. Розроблена модель електромеханічної системи гідротранспорту. Перевірка однорідності за критерієм Фішера й Бартлетта показала однорідність оцінок дисперсії відтворюваності. Для критерію Фішера значення було 2,59; для перевірки критерію Бартлетта було показано, що значення коефіцієнту на рівні менше 0,02, що вказує на надійність розрахунку кореляційної матриці.

Наукова новизна. Уперше була застосована модель для систем гідравлічного транспорту на основі моделей багатомасових роторів Джеффкотта. При моделюванні враховується знос обладнання у процесі функціонування.

Практична значимість. Була доведена ефективність використання моделі багатомасових роторів Джеф- фкотта. Це дозволяє надійно описати поведінку об'єкта в конкретних технологічних режимах і підвищити ефективність процесів.

Ключові слова: динамічне моделювання, ротор Джеффкотта, мультимасова модель, гідротранспорт

Цель. Построение и анализ модели электромеханической системы гидротранспорта обогатительных фабрик, которая сможет учитывать изменения, связанные с износом оборудования, а также производить накопление технических изменений, вызванных эксплуатацией трубопроводной системы.

Методика. Динамическая модель электромеханической системы гидротранспорта разработана на основе данных о физических параметрах гидротранспортных систем, полученных эмпирически. Она основана на методах идентификации динамических систем в виде дифференциальных уравнений для элементов технологического объекта гидравлического транспорта внутри завода.

Результаты. Разработана модель электромеханической системы гидротранспорта. Проверка однородности по критерию Фишера и Бартлетта показала однородность оценок дисперсии воспроизводимости. Для критерия Фишера значение было 2,59; для проверки критерия Бартлетта было показано, что коэффициент значителен на уровне менее 0,02 , что указывает на надежность расчета корреляционной матрицы.

Научная новизна. Впервые была применена модель для систем гидравлического транспорта на основе моделей многомассовых роторов Джеффкотта. При моделировании учитывается износ оборудования в процессе функционирования.

Практическая значимость. Была доказана эффективность использования модели многомассовых роторов Джеффкотта. Это позволяет надежно описать поведение объекта в конкретных технологических режимах и повысить эффективность процессов.

Ключевые слова: динамическое моделирование, ротор Джеффкотта, мультимассовая модель, гидротранспорт

Рекомендовано до публікації докт. техн. наук В.В. Ткачовим. Дата надходження рукопису 28.12.17. 